\title{
竹原義二の独立住宅作品に見るアプローチ空間の設計手法に関する研究 A STUDY ON THE APPROACH ARRANGEMENT METHOD IN DETACHED HOUSE WORKS OF YOSHIJI TAKEHARA
}

\author{
李 路 陽 ${ }^{* 1}$, 遠藤秀平*2 \\ Luyang LI and Shuhei ENDO
}

\begin{abstract}
Japanese architect Yoshiji Takehara is known as a residential master because of his large amount of built housing works. From his discourse and work commentary on housing design, it is often seen to place importance on the arrangement of approaches. Therefore, this study is focusing on the approach design of detached house works of him, by analyzing the arrangement method and space composition of these approaches, the design methods have been revealed as follows:

(1). The time axis of approach has been extended by extending the overall length of streamline and adding turn, thus creates a transitional space before entering the house and makes the limited space widely felt.

(2). A variety of spatial experience of approach have been made by arranging space with different limitation. Thus increased the contrast of approach space and brings sensual transitions and diverse spatial experiences.
\end{abstract}

Keywords : Yoshiji TAKEHARA, Detached House, Approach, Tortuosity, Arrangement form 竹原義二, 独立住宅, アプローチ, 曲折性, 配置形態

1. はじめに

\section{1 竹原義二とその住宅設計観}

建築家竹原義二氏は、数多くの建築作品を実現し注 ${ }^{1)}$ 、特に住宅、 保育所、老人施設など人の暮らしを原点にしたものが多いことから、 住宅作家とも言われている注2)。1980 年代以後、手掛けた作品が住 宅設計専門誌に 100 回以上掲載され注 ${ }^{3)}$ 、注目を集めている。

このように建築専門誌への掲載頻度が高く、長年に渡って注目さ れている竹原の住宅作品に対し、花田佳明は作品の完成度の高さや スタイルの経年的変化がないことを評価している注4)。つまり、一貫 性のある作品として安定性が示されていると言えるだろう。また、 竹原氏の言説や作品解説を概観的に見ると、人を内部空間まで誘う アプローチ空間の配置を大切にしていること注 5)、特に玄関まで容易 に到着させず、動線を折れ曲がりにすることで人を立ち止まらせる 配慮が多く見受けられる注 6) 注 7)。例えば、1985 年に竣工された、間 口 $3.5 \mathrm{~m}$ 、奥行約 $10 \mathrm{~m}$ の極小敷地にある「粉浜の家 $2 」$ のアフロー チは、建物と道路の間に配置された小さなコートを経て内部に入る までに 4 回の折れ曲がりが見られる。このようにアプローチ空間の 配置は竹原義二の住宅設計にとって重要なキーワードとしてあげら れる。

また、住宅のアプローチ空間に対して、藤江通昌は玄関に到達す るまでをドラマにたとえ、居住者のみならず外部の人々にも四季の
変化や落ち着いた雰囲気を提供し、良い町並みを形成する大きな手 段であると記述している注 8$)$ 。また、宮脇檀や平野敏之らも住宅設計 におけるアプローチへの配慮が見受けられる注 9) 注 10)。

以上の点から、アプローチ空間の配置は住宅設計にとって不可欠 な項目であり、その設計方法の分析は竹原の住宅設計観における重 要な項目である考えられる。

\section{2 関連研究のレビューと本研究の目的}

独立住宅の設計手法についての関連研究は、大きく分けると、住 宅の内部空間における室の形状や配列による空間の分節形式注 ${ }^{11}$ 、 内外部空間の構成やつながり方注 ${ }^{12)}$ 、外部空間の形態や構成注 ${ }^{13)}$ など を検討したものに分類できる。その内、特定の建築家の作品を対象 とした研究としては、吉田五十八の作品に見る近代住宅の出入口の 変容を明らかにしたもの注 ${ }^{14)}$ 、清家清の住宅作品における空間の伸 縮性を考察したもの注 ${ }^{15)}$ 、竹原義二の住宅作品を通した写真や言葉 の解析からその光と影、素材に見る暗さの手法による内外の空間関 係を考察したもの注 ${ }^{16)}$ などがある。また、一般建築作品のアプロー チの形態や歩行体験について考察したものがあげられる注 17) 注 18)。

住宅を対象にした内外空間の関係に着目した研究は、内外空間の 位置関係や各室と外部のつながり方、内外部空間の境界などから解 析したものがほとんどであり、人を住宅内部に誘うアプローチ空間 のあり方に着目したものは見当たらない。本研究はアプローチ空間
*1 神戸大学大学院工学研究科建築学専攻 博士後期課程 . 工修

*2 神戸大学大学院工学研究科建築学専攻 教授. 工博 
の具体的な形態に着目し、アプローチ空間を長年に亘り大切にしつ づけてきた竹原義二の独立住宅作品を対象に、そのアプローチの設 計手法を解析することで、竹原の独立住宅設計手法の一端を明らか にすることを目的とする。

\section{2. 研究の方法}

本研究は竹原義二の作品や著作など資料の調查や作品の分析を中 心に、本人へのインタビューにより補足する方法で進められた。

資料調査については、竹原義二の著作、雑誌に掲載された作品と 解説から、住宅アプローチに関わるキーワードや設計意図を整理し、 住宅専門雑誌から竹原義二の独立住宅作品 78 件を対象作品として 抽出した注 ${ }^{19)}$ 。作品分析については、資料から把握した設計意図に 示されたアプローチの指標を数值で測った上で、対象作品のアプロ 一チ注 20)を住棟との位置関係やアプローチ動線の長さ、曲折性など に見る「配置形態」、及びアプローチがどんな空間で構成されている かという「空間構成」の二つの側面から、アプローチの数量指標の 検討と類型化を行った。配置形態」については、その類型化を行い、 多変量分析でアプローチの形態と配置条件との関係性を検討し、作 品のアプローチ空間の特徵を明らかにした。「空間構成」については、 数值的な指標の確定が困難なため、定性分析の形で進められた。さ らに、竹原の作品と同時期の一般作品とを比較することで、竹原義 二の住宅アプローチの設計手法を明らかにした。これらの具体的分 析項目は表 1 に示している。インタビューは 2016 年 1 月 28 日に 実施した。

Table 1 Research method

\begin{tabular}{|c|c|c|}
\hline \multirow{2}{*}{\multicolumn{2}{|c|}{ 資料調查 }} & 【 言説からアプローチに期待する設計意図を抽出 \\
\hline & & ～専門雑誌に掲載された対象作品を抽出 \\
\hline \multirow{3}{*}{ 作品分析 } & 配置形態 & 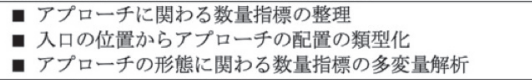 \\
\hline & 空間構成 & $\begin{array}{l}\text { - アプローチの空間と曲り方の類型化 } \\
\text { 口設計意図、アフィローチの空間類型と上記数量指標の検討 }\end{array}$ \\
\hline & その他 & ～配置形態と空間構成の結果と一般住宅作品との比較 \\
\hline \multicolumn{2}{|c|}{ インタビュー } & 場所 : 無有建築工房(大阪) \\
\hline
\end{tabular}

\section{3. 言説からアプローチに期待する設計意図の抽出}

事例に対する竹原本人の言説(著作における解説)をベースとして、 資料から筆者の解釈を加えて、アプローチの配置に対する主要な設 計意図を読み取った。以下、4つの項目に分類した設計意図及び代 表的な言説を記載する。

1）動線を長く取る

アプローチ動線をより長く取り、人が住棟に入るまでの時間軸を 延長する。

ロ私はアプローチの空間は、できるだけ長く取るように心掛けて いる。(参考文献 2, p103)

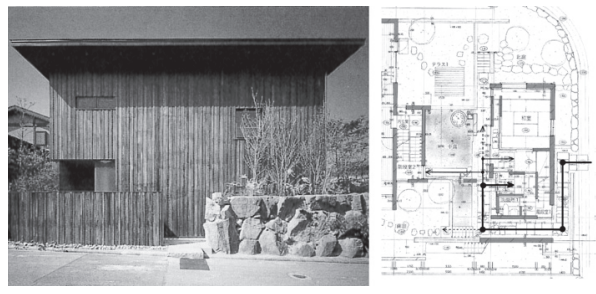

Fig. 1 House of Shinsenriminamimachi
2) 折れ曲がりにする

アプローチ動線を折れ曲がらせることで、人を立ち止まらせたり、 向きを変えさせたりする。

口玄関へ容易に到達させない。敷地に余裕がなく、アプローチ空 間をほとんど取ることができない場合でも、必ず一度は立ち止まら せる。(参考文献 $2, \mathrm{p} 103$ )

口訪れた人は様々な表情をもって地面から立ち上がる壁を巡って 折れ曲がった石敷きの路地空間を歩むとき、立ち止まることによっ て間を保ちながら空間の奥行きやつながりを感じることができる。

(東広島の家)
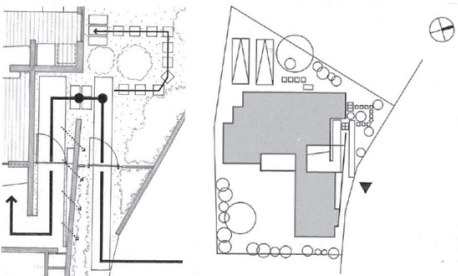

Fig. 2 House of Hozancho

3）玄関扉の内外空間を同質にする（内外同質と記述）

アプローチの床材が玄関ドアの内側まで伸びる。

ロ「石丸の家」は石貼壁のヴォリュームから少し奥まったところ に玄関ドアがある。アプローチとして短いが、内部に同じ床仕上げ の路地空間が奥まで連続している。（参考文献 2, p106、石丸の家）
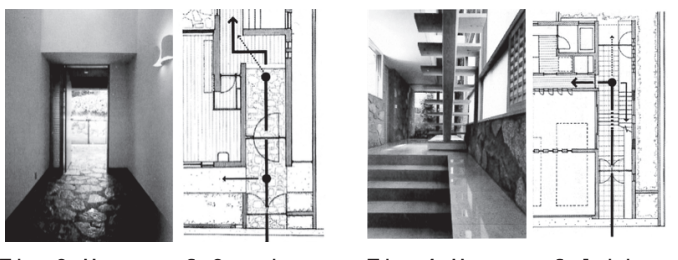

Fig. 3 House of Senrizan

Fig. 4 House of Ishimaru

4）空間の開放と閉鎖による変化を生かす（空間変化を生かすと記述） アプローチ動線として自立壁や建築外壁に挟まれたスキマ・トン ネル空間を通過させる。

ロ路地空間そのものは建物のスキマをほぼ直線的に進むだけであ るが、雨や太陽の光、風の行き交い、何気なく足を止めさせたり視 線の変化を促寸仕掛けが、至る処に施されているのである。（参考文 献 2, p110)

ロトンネルとなった路地をくぐり抜けると、ヴオイドの上部から 光の注ぐ内庭へと到る。連続する外部空間を「くぐる」という行為 によって曖昧につなぎ、内庭をより内なる領域として意識させてい る。(参考文献 2, p116、熟林寺南町の家)

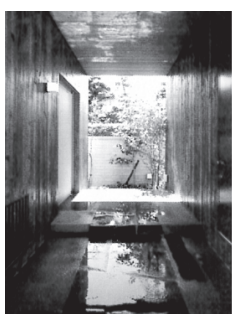

Fig. 5 House of Tetukayama

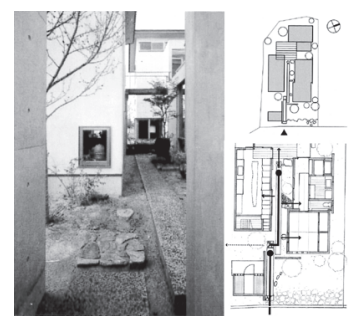

Fig. 6 House of koryosho 
以上、竹原の言説からアプローチに対する設計意図を大きく 40 に分類したが、これらはいずれも単独の目的としての存在している のではなく、互いに複合しながら成立するものも見られる。

上記の設計意図を明確化するために、設計意図に示されるアプロ 一チの指標を定量的に捉えた。「動線を長く取る」と「折れ曲がりに する」に対しては、対象事例の図面からアプローチ動線の水平距離、 曲り数を集計することで定量化した。「内外同質」に対しては、意図 を数值で捉えることは困難であるが、図面からの判断により該当事 例とそうでない事例に分類し、それらのアプローチの長さ、曲り数 の指標を検討し、意図の「内外同質」とアプローチ動線の基本形態 との関係を明らかにした。アプローチにおける「空間変化を生かす」 に対しては、全事例のアプローチの空間を空間の限定性により類型 化し、作品ごとに空間の変化や各類型の全事例に対する割合を整理 した。

\section{4. 対象事例の概要}

\section{1 対象事例の基本情報}

アプローチの配置形態を分析するために、まず対象作品の基本条 件と諸指標を整理した。図 7 では、全対象作品の敷地面積、建築面 積、延床面積、建蔽率、アプローチの水平距離、動線の曲り数など の情報を整理した。横軸は各項目の数值であり、縦軸は該当する事 例数である。図 7 を見ると、敷地面積では、 $100 \mathrm{~m}^{2}$ 未満の事例から $500 \mathrm{~m}^{2}$ 以上の事例まで見られる。建築面積では、ほとんどの事例 $(63$ 件）が 20 140 m²に集中していることが示された。延床面積では、 73 事例が 50 300 $\mathrm{m}^{2}$ の範囲内にあり、300 $\mathrm{m}^{2}$ 以上の事例は少ない。 建蔽率では、ほとんどが 0.2 0.6 となっている。アプローチ動線の 水平距離では、約半分の事例（37 件）が $5 \sim 10 \mathrm{~m}$ に該当しており、 平均值は $8.25 \mathrm{~m}$ である。アプローチ動線の曲り数注 21$)$ では、 1 と 2 に該当する事例が多く見られる。

上記の数值から、対象作品は敷地面積が $100 \mathrm{~m}^{2}$ 以内の狭小住宅か ら、500 m²以上大型住宅まで幅広く見られ、アプローチは $8 \mathrm{~m}$ 前 後、曲りは 1 回及び 2 回が平均的な実態と推定できる。

\section{2 アプローチの水平距離と敷地規模の関係}

敷地面積に対するアプローチ動線の水平距離の散布図は図 8 に示 している。敷地面積に対してアプローチの水平距離との間に正の相 関が示された。

アプローチ水平距離 $=0.016 \times$ 敷地面積 +5.4 （相関 0.66）

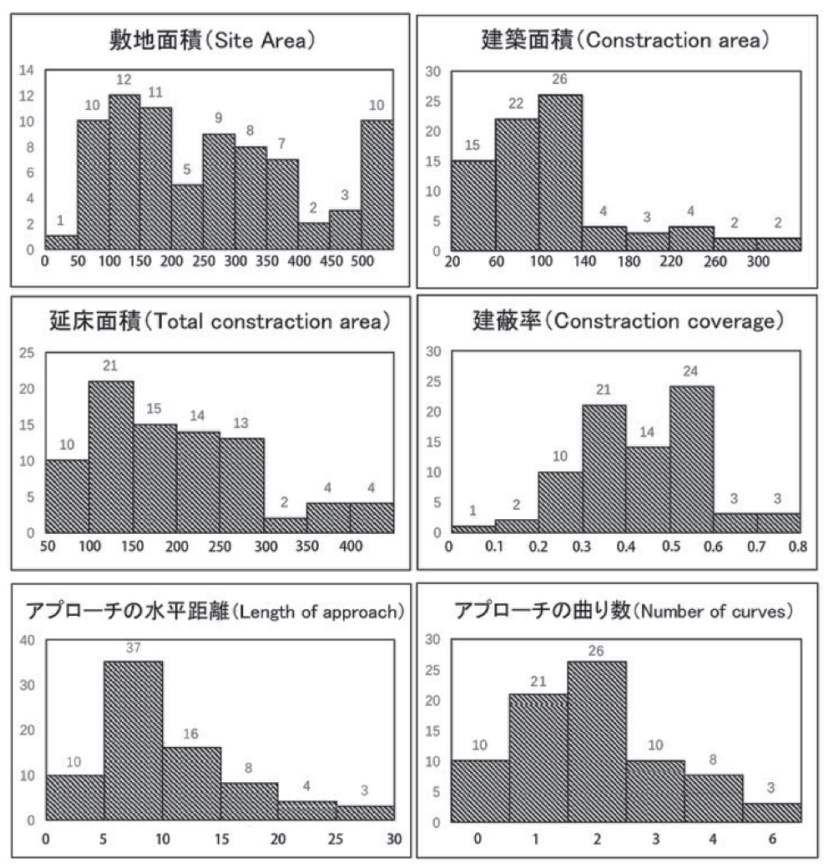

Fig. 7 Information of objects

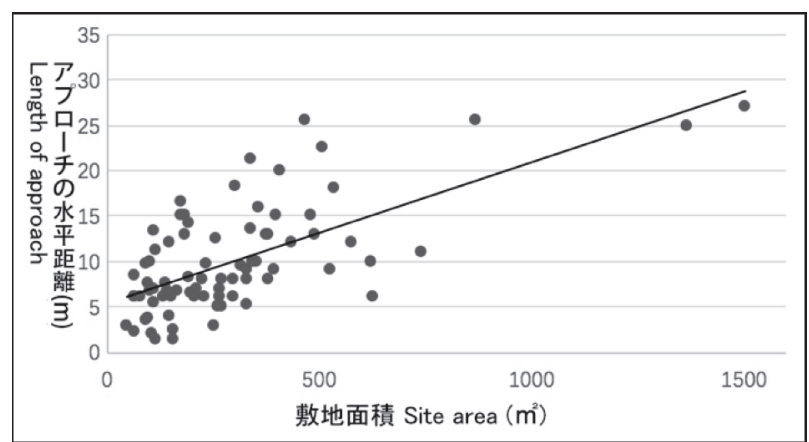

Fig. 8 Site area $\times$ length of approach

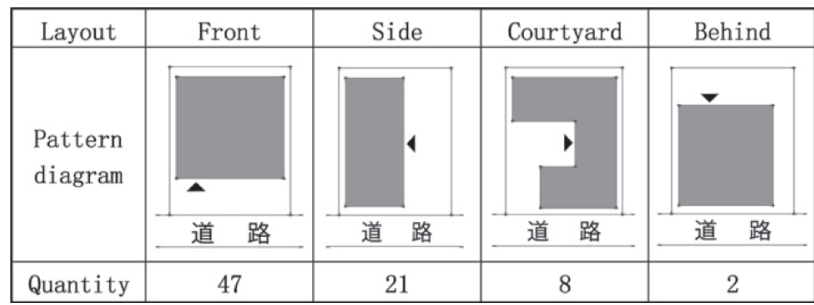

Fig. 9 Approach layout from entrance position

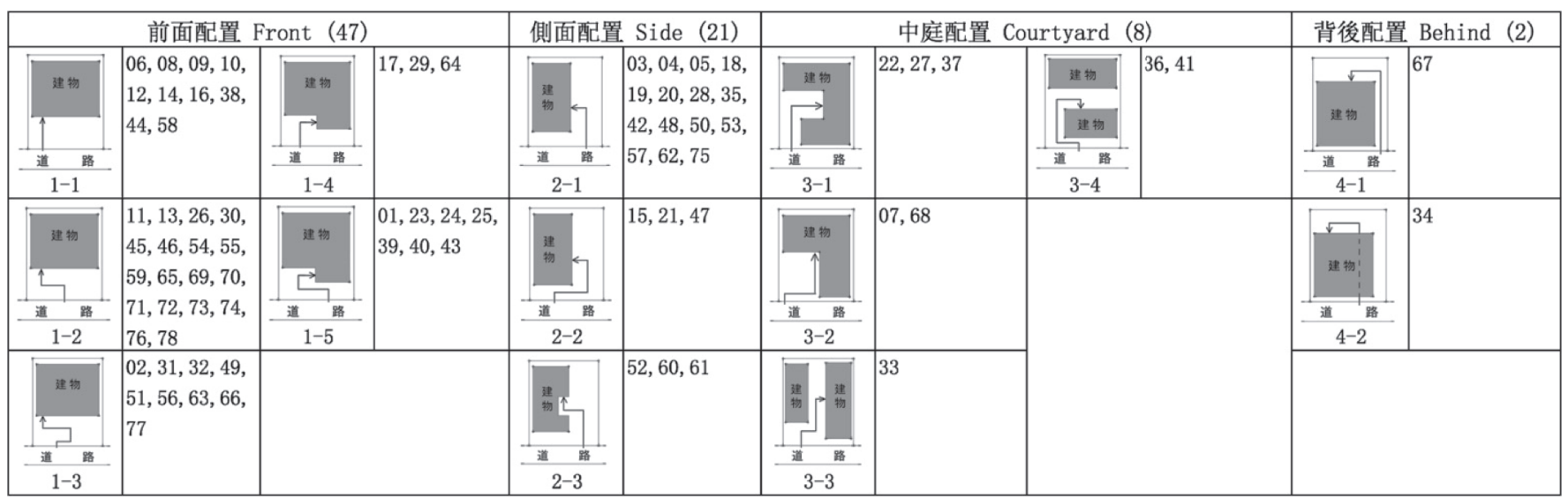

Fig. 10 Particular forms of approach from the approach layout 


\section{3 入口の位置からアプローチの配置を類型化}

次に、アプローチと住棟の位置関係や玄関ドアの所在位置による アプローチの配置を類型化する。アプローチの配置類型はアプロー チ動線の終点である玄関ドアの所在位置との関係が深いと考えられ るため、玄関ドアが住棟の前側にあるか横側にあるかなど玄関ドア の住棟に対する所在位置によりアプローチを図 9 のように、4つの 類型に分けた。玄関ドアが建築の前面方向注 22) に位置する場合は「前 面配置」に、建築の横に位置する場合は「側面配置」に、アプロー チ動線が建築ヴオリュームに囲まれた中庭を経て、そこに位置する 玄関ドアに到着するものを「中庭配置」に、玄関ドアが建築の奥側 に位置するものを「背後配置」にする。その結果、事例数の最も多 い類型は「前面配置」(47/78)であった。さらに、アプローチの曲り 数により配置類型ごとにいくつかの具体的な形態とその対応する事 例を図 10 のように整理した。

\section{4 その他の計量化指標}

他に計量化のための指標として求めたものを以下に列記する。

敷地針状度 敷地短辺/敷地長辺

$\checkmark$ 敷地南面率 敷地東西長/敷地南北長

\section{接道距離}

接道距離率 接道距離/（「敷地面積）

接道数

主要接道方位

$\square$ 玄関距離 玄関ドアと前面道路の水平距離

\section{5. アプローチの形態に関わる数量指標の多変量解析}

本章では、これまでに集計したデータ(4.1 と 4.4)をもとに、アプ ローチの特性に関わる指標に対する他の指標の影響度を考察するた め、重回帰分析を行った。(アプローチに関わる 1 つの指標を外的基 準にとり、その他のすべての数量指標を説明変数とした。解析法は、 $\mathrm{F}$ 值 $>2.00$ としたステップワイズ法による。）（表 2）

ここでは、当然相関のある指標を除き、有意な影響力を持つと考 えられる指標について以下のように考察できた。

(1)アプローチの水平距離では、少ないながらも敷地の接道距離が 正の相関を持ち、接道距離が長いほどアプローチを長く取る傾向が 示された。

(2)アプローチの曲り数では、玄関距離と負の相関があり、玄関が 前面道路の近くに配置され、アプローチを長く取れない場合、その 動線を折れ曲がりにする手法が見られた。

(3) 立関距離は、接道距離にほぼ影響されず接道距離率に強い負の 相関を持っているが、これは間口（接道距離）が狭い狭長な大型敷 地の場合、玄関が奥部に配置され、玄関距離を長くする傾向を示し ている。また、玄関距離は接道方向に正の相関を持つことから、接 道方向が日当たりの良い方向の場合、立関距離を長く取る傾向が示 されている。

以上の結果から、竹原が考えたアプローチ空間はどんな配置条件 においても、意図的にアプローチ空間の時間軸を意識し、アプロー チを長く取る傾向が窥える。

\section{6. アプローチの空間構成の検討}

本章では、アプローチ動線の所在空間の限定性 $\left.{ }^{2} 23\right)$ の変化、アプロ
Table 2 Result of regression analysis

\begin{tabular}{|l|c|c|c|}
\hline & $\begin{array}{c}\text { Length of approach } \\
\text { アプローチの水平距䜅 }\end{array}$ & $\begin{array}{c}\text { Number of curves } \\
\text { アプローチの曲り数 }\end{array}$ & $\begin{array}{c}\text { Distance of entrance } \\
\text { 幺関距離 }\end{array}$ \\
\hline $\begin{array}{l}\text { Length of connect road } \\
\text { 接道距離 }\end{array}$ & 0.16 & & -4.38 \\
\hline $\begin{array}{l}\text { Rate of above } \\
\text { 接道距離率 }\end{array}$ & & & 0.45 \\
\hline $\begin{array}{l}\text { Direction of road } \\
\text { 主要接道方向 }\end{array}$ & & 0.27 & 0.72 \\
\hline $\begin{array}{l}\text { Length of approach } \\
\text { アプローチの水平距離 }\end{array}$ & & & -1.18 \\
\hline $\begin{array}{l}\text { Number of curves } \\
\text { アプローチの曲り数 }\end{array}$ & 1.74 & -0.24 & 4.52 \\
\hline $\begin{array}{l}\text { Distance of entrance } \\
\text { 玄関距離 }\end{array}$ & 0.96 & 0.82 & 0.92 \\
\hline $\begin{array}{l}\text { Intercept } \\
\text { 切片 }\end{array}$ & -2.14 & 0.76 & 0.83 \\
\hline $\begin{array}{l}\text { Multiple correlation R } \\
\text { 重相関R }\end{array}$ & 0.93 & 0.56 & \\
\hline $\begin{array}{l}\text { Correction R2 } \\
\text { 補正R2 }\end{array}$ & 0.86 & & \\
\hline
\end{tabular}

一チ動線の折れ曲がりを発生させる方法(曲り方)などの解析から、 アプローチ空間の物理形態の特徵を検討した。

まず、全事例のアプローチ動線の折れ曲がりを発生させる要素(折 れ曲がり要素と呼ぶ）とアプローチ空間の開放性を分類した。図 11 のように、折れ曲がりを発生させる要素を壁、樹木など「立体要素」 と床面の舗装材やレベルの変化など「床面要素」に分けた。「立体 要素」では、動線が壁や樹木に突き当たってから曲がる場合は「壁」 と「樹木」に、動線が他空間領域に入るために曲がる場合は「空間 分節」に、また、「壁」に関して、壁の高さが目線の高さより低い ものを「低い壁」にした。「床面要素」では、舗装材の曲がりによ り動線を曲がらせる場合は「舗装」に、舗装材と芝などの非歩行材 との境界により動線を曲がらせる場合は「床材分節」に、階段や床 面のレベルの変化により曲がらせる場合は「階段」と「レベル変化」 として。以上、折れ曲がり要素は計 8 種類に区分され、折れ曲がり 方は記号 $\mathrm{A} \sim \mathrm{H}$ と記述する注 ${ }^{24)}$ 。1 つの折れ曲がりが複数の要素に 該当する場合、該当する要素の記号を合わせて記述する(例：BE)。

アプローチ空間の限定性の分類では、図 12 のようにアプローチ の所在空間を開放感の強い順に、物理的空間制限のない「開放」、動 線の片側に壁がある「片側壁」、片側の壁の上から屋根を伸ばし動線 の上空を覆う「片側開放」、両サイドに壁があるがどちらかが目線の 高さ以下である「準スキマ」、動線が平行する二つの建築外壁や自立 壁に挟まれている「スキマ」、建築ヴォリュームの領域を通過する「ト ンネル」と建築ヴオリュームが凹んで形成した「凹み」に分けた。 上記の 7 つの空間類型に関して、記号は開放感の強い順に(1)〜 (7) と する。以上の折れ曲がり方、空間の類型を、アプローチ動線の各区 間の距離の情報と合わせ、全事例でのアプローチ空間の物理実態を 図 13 のように、横棒グラフにより表現した。

図 13 では、縦軸を事例番号とし、横軸をアプローチ動線の水平 距離としている。事例ごとに示寸各横棒の上部はアプローチの折れ 曲がりにより分割した各区間の水平距離と折れ曲がり方が標記され ている。下部は該当部分の空間類型を表現している。塗りつぶしは 図 12 の空間類型の (1)〜 (7) に対応している。(凡例を参照)

全事例における各折れ曲がり方とその事例数を表 3 のように整理 した。事例数の多い類型は「E」(29 件)、「C」(27 件)、「B」(24 件)、 $\lceil\mathrm{BE} 」(22$ 件 $)$ である。次に、 5 つ以上の事例数がある類型の折れ曲 がり方を主要類型としてピックアップし、これらを立体要素のみ、 


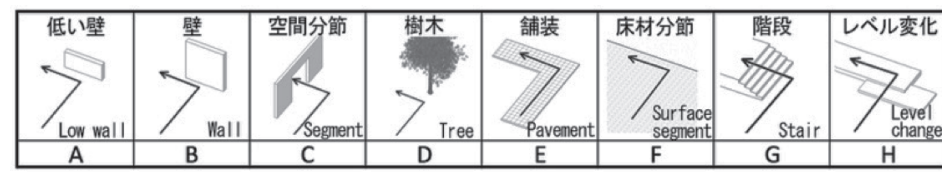

Fig. 11 Elements that initiat the curve

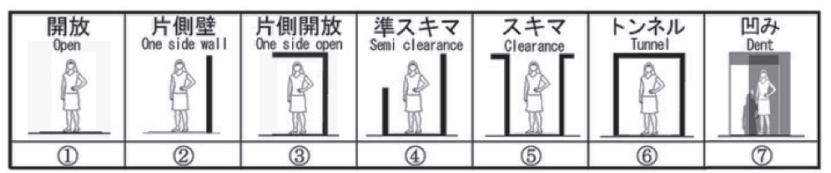

Fig. 12 Types of space from the openness

\begin{tabular}{|l|l|l|}
\hline & \multicolumn{1}{|c|}{20} \\
\hline
\end{tabular}

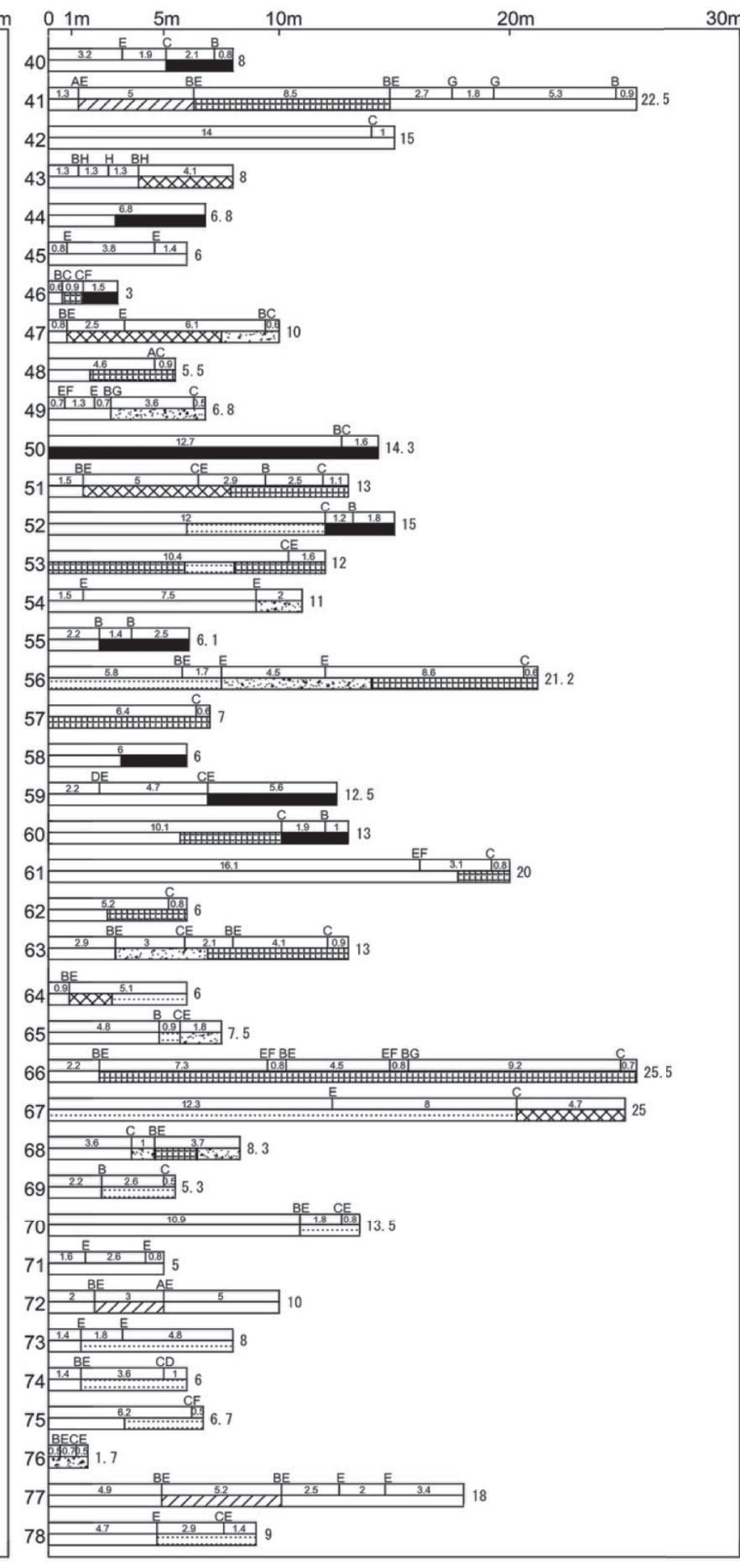

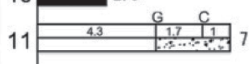

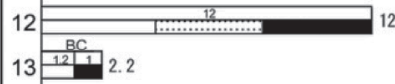

${ }_{14}^{2} \stackrel{2}{\rightleftharpoons} 2$

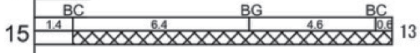

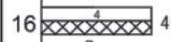

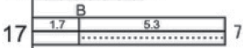

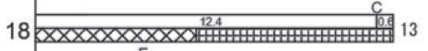

$1 9 \longdiv { 4 \quad E \quad 1 1 }$

$2 0 \longdiv { D _ { 1 3 } } 6$

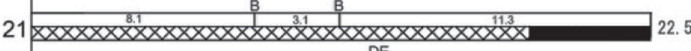

$2 2 \longdiv { \text { DE } } 3 9 . 5$

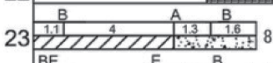

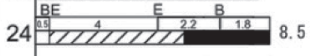

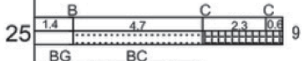

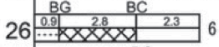

\begin{tabular}{l}
$27 \quad 30$ \\
\hline$\quad 39$
\end{tabular}

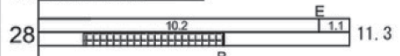

329

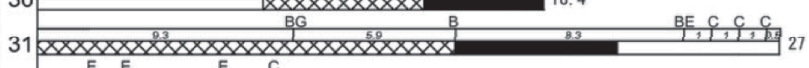

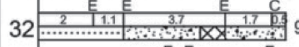

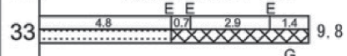

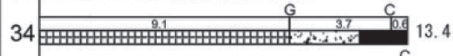

35 BE

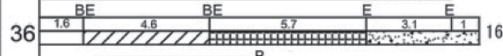

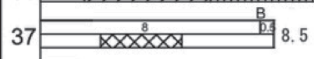

381.5

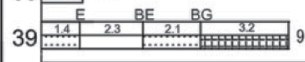

Fig. 13 Physical composition of approach

床面要素のみと両方の組合せに分けて、事例数の年代的変化を表 4 のように検討した。結果として、初期の 1980 年代には「立体要素」 が全事例を占め、年代の経過とともに「床面要素」や「両方の組合 せ」に該当する類型が増加する。しかし、2010 年以後は「立体要素」
が少数になり、床面の仕上げ材やレベル差の操作を含んだ折れ曲が り方が主流になることが示された。このことから、壁など立体的な 要素により折れ曲がりを発生させるタイプから、床材やレベル差の 操作により曲がらせるタイプに変化する傾向が見られる。 
アプローチ空間の開放性の変化を見ると、全事例のアプローチ空 間は一つの空間類型のみがあるものの他に複数の空間類型を組合せ たものが見られる。空間の開放性がどのように変化するかに関して、 表 5 のように、変化のない「無変化」一度変化する「減少」と「増 加」、二度変化する「減少 $\rightarrow$ 増加」と「増加 $\rightarrow$ 減少」の 5 つの種類が あげられ、それらの事例数を整理した。その結果、開放性のより高 い空間からより閉鎖的な空間に変化する「減少」の事例が全体の半 分以上 $(45 / 80)$ を占め、最も主要な変化のタイプであることが示さ れた。また、空間の開放性が変化したタイプが 64 事例を占めるこ とから、竹原の作品にはアプローチ空間の開放性の变化を求める傾 向が指摘できる。

\section{7. 設計意図と諸条件の検討}

本章では、前述の設計意図に対して、アプローチの配置類型と空 間の実態がどのように関わっているかを検討する。表 6 のように、
横軸をアプローチの配置類型に、縦軸を設計意図にする。全事例を 該当する箇所に記載し、アプローチの具体的な形態、水平距離、曲 り数、空間の開放性変化の種類などの情報を含めて整理した。

設計意図の該当事例数を見ると、「動線を長く取る」注 25$)(59 / 78)$ 、

「折れ曲がりにする」注26) (48/78) と「空間変化を生かす」(38/78)が 多用されていることが示された。各設計意図の事例における配置類 型ごとの割合を見ると、「動線を長く取る」はどの配置類型でも事例 の大半を占めていることから、アプローチに対する最も重要な設計 手法としてあげられる。「折れ曲がりにする」では、「前面配置」と

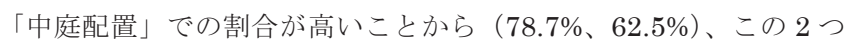
の配置類型において、アプローチ動線を折れ曲がらせる傾向が示さ れた。また、「空間変化を生か寸」は「側面配置」と「中庭配置」の 事例で多用されること $(71.4 \% 、 87.5 \%)$ から、アプローチ動線が建 築ヴォリュームやスキマを通り抜けることで、住棟の脇または奥部 に到達することが読み取れた。
Table 3 Object number of curve type

\begin{tabular}{|c|c|c|c|}
\hline Type & Number & Type & Number \\
\hline E & 29 & A & 3 \\
\hline C & 27 & CF & 3 \\
\hline B & 24 & DE & 2 \\
\hline BE & 22 & BH & 3 \\
\hline BC & 9 & AE & 2 \\
\hline CE & 8 & DF & 1 \\
\hline BG & 6 & H & 1 \\
\hline EF & 4 & AC & 1 \\
\hline G & 4 & $\mathrm{CD}$ & 1 \\
\hline
\end{tabular}

Table 4 Changing of curve types

\begin{tabular}{|c|c|c|c|c|c|}
\hline Type & $1980 \mathrm{~s}$ & $1990 \mathrm{~s}$ & $2000 \mathrm{~s}$ & $2010 \mathrm{~s}$ & Total \\
\hline c & 3 & 10 & 13 & 1 & 27 \\
\hline$\omega$ & 5 & 10 & 8 & 1 & 24 \\
\hline$B C$ & 1 & 5 & 3 & 0 & 9 \\
\hline \begin{tabular}{|l|} 
Total \\
\end{tabular} & 9 & 25 & 24 & 2 & 60 \\
\hline $\mathrm{BE}$ & 0 & 4 & 12 & 6 & 22 \\
\hline $\mathrm{CE}$ & 0 & 0 & 5 & 3 & 8 \\
\hline $\mathrm{BG}$ & 0 & 3 & 3 & 0 & 6 \\
\hline Total & 0 & 7 & 20 & 9 & 36 \\
\hline$E$ & 0 & 11 & 11 & 7 & 29 \\
\hline $\mathrm{EF}$ & 0 & 0 & 4 & 0 & 4 \\
\hline Total & 0 & 11 & 15 & 7 & 33 \\
\hline
\end{tabular}

Table 5 Changing of space openness

\begin{tabular}{|c|c|c|c|}
\hline Changing types & Pattern diagram & Ob ject №. & Total \\
\hline $\begin{array}{l}\text { No change } \\
\text { 無变化 }\end{array}$ & & $\begin{array}{l}05,06,09,10,14,16,19,38,42, \\
45,50,57,71,76\end{array}$ & 14 \\
\hline $\begin{array}{l}\text { Reduce } \\
\text { 蔵少 }\end{array}$ & & 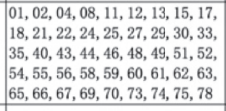 & 45 \\
\hline $\begin{array}{l}\text { Increase } \\
\text { 增加 }\end{array}$ & & $03,20,23$ & 3 \\
\hline $\begin{array}{l}\text { Reduce } \rightarrow \text { Increase } \\
\text { 娍少 } \rightarrow \text { 增加 }\end{array}$ & & $\begin{array}{l}07,26,28,31,32,36,37,41,47 \\
64,, 88,72,77\end{array}$ & 13 \\
\hline $\begin{array}{l}\text { Increace } \rightarrow \text { Reduce } \\
\text { 增加 } \rightarrow \text { 娍少 }\end{array}$ & 道-閣-開)閉- & $34,39,53$ & 3 \\
\hline
\end{tabular}

Table 6 Consideration of the design intention and approach layout

\begin{tabular}{|c|c|c|c|c|c|c|c|c|}
\hline \begin{tabular}{c|} 
Intention \\
設計意図 \\
\end{tabular} & \multicolumn{3}{|c|}{$\begin{array}{l}\text { Front (47) } \\
\text { 前面配置 } \\
\end{array}$} & \multicolumn{2}{|c|}{$\begin{array}{c}\text { Side }(21) \\
\text { 側面配置 } \\
\end{array}$} & $\begin{array}{l}\text { Courtyard (8) } \\
\text { 中庭配置 }\end{array}$ & $\begin{array}{l}\text { Behind(2) } \\
\text { 背後配置 } \\
\end{array}$ & $\begin{array}{l}\text { Total } \\
\text { 計 }\end{array}$ \\
\hline $\begin{array}{l}\text { Making } \\
\text { root } \\
\text { longer } \\
\text { 動線を } \\
\text { 長く取る }\end{array}$ & $\begin{array}{l}01,1-5,6.5 \mathrm{~m}, 3, \text { Reduce } \\
02,1-3,3.5 \mathrm{~m}, 2, \text { Reduce } \\
12,1-1,12 \mathrm{~m}, 0 \text {, Reduce } \\
23,1-5,8 \mathrm{~m}, 3 \text {, Increase } \\
24,1-5,8.5 \mathrm{~m}, 3 \text {, Reduce } \\
25,1-5,9 \mathrm{~m}, 1 \text {, Reduce } \\
29,1-4,8 \mathrm{~m}, 1 \text {, Reduce } \\
30,1-2,18.4 \mathrm{~m}, 2 \text {, Reduce } \\
31,1-3,27 \mathrm{~m}, 6, \mathrm{R} \rightarrow \mathrm{I} \\
32,1-3,9 \mathrm{~m}, 2, \mathrm{R} \rightarrow \mathrm{I} \\
39,1-5,9 \mathrm{~m}, 3, \mathrm{I} \rightarrow \mathrm{R} \\
40,1-5,8 \mathrm{~m}, 3 \text {, Reduce }\end{array}$ & $\begin{array}{l}43,1-5,8 \mathrm{~m}, 3, \text { Reduce } \\
44,1-1,6.7 \mathrm{~m}, 0 \text {, Reduce } \\
45,1-2,6 \mathrm{~m}, 2, \text {, No change } \\
46,1-2,3 \mathrm{~m}, 2 \text {, Reduce } \\
49,1-3,6.7 \mathrm{~m}, 4 \text {, Reduce } \\
51,1-3,13 \mathrm{~m}, 4 \text {, Reduce } \\
54,1-2,11 \mathrm{~m}, 2 \text {, Reduce } \\
\text { e } 55,1-2,6.1 \mathrm{~m}, 2 \text {, Reduce } \\
56,1-3,21.3 \mathrm{~m}, 4 \text {, Reduce ? } \\
58,1-1,6 \mathrm{~m}, 0 \text {, Reduce } \\
59,1-2,12.5 \mathrm{~m}, 2 \text {, Reduce ? } \\
63,1-3,10 \mathrm{~m}, 3 \text {, Reduce }\end{array}$ & $\begin{array}{l}64,1-4,10 \mathrm{~m}, 1, \mathrm{R} \rightarrow \mathrm{I} \\
65,1-2,7.5 \mathrm{~m}, 2 \text {, Reduce } \\
66,1-3,25.5 \mathrm{~m}, 6 \text {, Reduce } \\
69,1-2,5.3 \mathrm{~m}, 2, \text { Reduce } \\
70,1-2,13.5 \mathrm{~m}, 2, \text { Reduce } \\
71,1-2,5 \mathrm{~m}, 2, \text { No change } \\
72,1-2,10 \mathrm{~m}, 2, \mathrm{R} \rightarrow \mathrm{I} \\
73,1-2,6 \mathrm{~m}, 2, \text { Reduce } \\
74,1-2,6 \mathrm{~m}, 2, \text { Reduce } \\
76,1-2,1.5 \mathrm{~m}, 2, \text { No change } \\
77,1-3,18 \mathrm{~m}, 4, \mathrm{R} \rightarrow \mathrm{I} \\
78,1-2,10 \mathrm{~m}, 2, \text { Reduce }\end{array}$ & $\begin{array}{l}15,2-2,13 \mathrm{~m}, 3, \text { Reduce } \\
18,2-1,13 \mathrm{~m}, 1, \text { Reduce } \\
19,2-1,1 \mathrm{~m}, 1 \text {, No change } \\
20,2-1,6 \mathrm{~m}, 1 \text {, Increase } \\
21,2-2,22.5 \mathrm{~m}, 2, \text { Reduce } \\
28,2-1,11.3 \mathrm{~m}, 1, \mathrm{R} \rightarrow \mathrm{I} \\
47,2-2,10 \mathrm{~m}, 3, \mathrm{R} \rightarrow \mathrm{I}\end{array}$ & $\begin{array}{l}50,2-1,14.3 \mathrm{~m}, 1 \text {, No change } \\
52,2-3,15 \mathrm{~m}, 2 \text {, Reduce } \\
53,2-1,12 \mathrm{~m}, 1 \text {, I } \rightarrow \mathrm{R} \\
57,2-1,7 \mathrm{~m}, 1 \text {, No change } \\
60,2-3,13 \mathrm{~m}, 2 \text {, Reduce } \\
61,2-3,20 \mathrm{~m}, 2 \text {, Reduce } \\
62,2-1,6 \mathrm{~m}, 1 \text {, Reduce }\end{array}$ & $\begin{array}{l}07,3-2,9.8 \mathrm{~m}, 2, \mathrm{R} \rightarrow \mathrm{I} \\
22,3-1,16.5 \mathrm{~m}, 1 \text {, Reduce } \\
33,3-3,9.8 \mathrm{~m}, 3 \text {, Reduce } \\
36,3-4,16 \mathrm{~m}, 4, \mathrm{R} \rightarrow \mathrm{I} \\
37,3-1,8 \mathrm{~m}, 1 \mathrm{R} \rightarrow \mathrm{I} \\
41,3-4,8 \mathrm{~m}, 6, \mathrm{R} \rightarrow \mathrm{I} \\
68,3-2,8.3 \mathrm{~m}, 2, \mathrm{R} \rightarrow \mathrm{I}\end{array}$ & $\begin{array}{l}34,4-2,13.4 \mathrm{~m}, 2, \mathrm{I} \rightarrow \mathrm{R} \\
67,4-1,25 \mathrm{~m}, 2, \text { Reduce }\end{array}$ & \\
\hline Total竐 & \multicolumn{3}{|c|}{$36 / 76.6 \%$} & \multicolumn{2}{|c|}{$14 / 66.7 \%$} & $7 / 87.5 \%$ & $2 / 100 \%$ & 59 \\
\hline $\begin{array}{l}\text { Increase } \\
\text { the curves } \\
\text { 折れ曲り } \\
\text { にする }\end{array}$ & $\begin{array}{l}01,1-5,6.5 \mathrm{~m}, 3 \text {, Reduce } \\
02,1-3,3.5 \mathrm{~m}, 2 \text {, Reduce } \\
11,1-2,7 \mathrm{~m}, 2 \text {, Reduce } \\
13,1-2,2.2 \mathrm{~m}, 1 \text {, Reduce } \\
17,1-4,7 \mathrm{~m}, 1 \text {, Reduce } \\
23,1-5,8 \mathrm{~m}, 3 \text {, Increase } \\
24,1-5,8.5 \mathrm{~m}, 3 \text {, Reduce } \\
25,1-5,9 \mathrm{~m}, 1 \text {, Reduce } \\
26,1-2,6 \mathrm{~m}, 2, \mathrm{R} \rightarrow 1 \\
29,1-4,8 \mathrm{~m}, 1 \text {, Reduce } \\
30,1-2,18.4 \mathrm{~m}, 2, \text { Reduce } \\
31,1-3,27 \mathrm{~m}, 6, \mathrm{R} \rightarrow \mathrm{I} \\
32,1-3,9 \mathrm{~m}, 2, \mathrm{R} \rightarrow \mathrm{I}\end{array}$ & 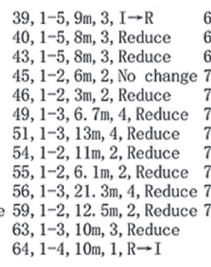 & $\begin{array}{l}65,1-2,7.5 \mathrm{~m}, 2 \text {, Reduce } \\
66,1-3,25.5 \mathrm{~m}, 6 \text {, Reduce } \\
69,1-2,5.3 \mathrm{~m}, 2 \text {, Reduce } \\
70,1-2,13.5 \mathrm{~m}, 2 \text {, Reduce } \\
71,1-2,5 \mathrm{~m}, 2, \text { No change } \\
72,1-2,10 \mathrm{~m}, 2, \mathrm{R} \rightarrow \mathrm{I} \\
73,1-2,6 \mathrm{~m}, 2, \text { Reduce } \\
74,1-2,6 \mathrm{~m}, 2, \text { Reduce } \\
76,1-2,1.5 \mathrm{~m}, 2, \text { No change } \\
77,1-3,18 \mathrm{~m}, 4, \mathrm{R} \rightarrow \mathrm{I} \\
78,1-2,10 \mathrm{~m}, 2, \text { Reduce }\end{array}$ & $\begin{array}{l}15,2-2,13 \mathrm{~m}, 3 \text {, Reduce } \\
21,2-2,22.5 \mathrm{~m}, 2, \text { Reduce } \\
47,2-2,10 \mathrm{~m}, 3, \mathrm{R} \rightarrow \mathrm{I} \\
52,2-3,15 \mathrm{~m}, 2, \text { Reduce } \\
60,2-3,13 \mathrm{~m}, 2, \text { Reduce } \\
61,2-3,20 \mathrm{~m}, 2 \text {, Reduce }\end{array}$ & & $\begin{array}{l}07,3-2,9.8 \mathrm{~m}, 2, \mathrm{R} \rightarrow \mathrm{I} \\
36,3-4,16 \mathrm{~m}, 4, \mathrm{R} \rightarrow \mathrm{I} \\
33,3-3,9.8 \mathrm{~m}, 3, \text { Reduce } \\
41,3-4,8 \mathrm{~m}, 6, \mathrm{R} \rightarrow \mathrm{I} \\
68,3-2,8.3 \mathrm{~m}, 2, \mathrm{R} \rightarrow \mathrm{I}\end{array}$ & 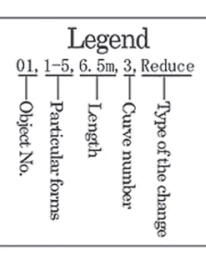 & \\
\hline Total竐 & \multicolumn{3}{|c|}{$37 / 78.7 \%$} & \multicolumn{2}{|c|}{$6 / 28.6 \%$} & $5 / 62.5 \%$ & & 48 \\
\hline $\begin{array}{l}\text { Continuing } \\
\text { inner and } \\
\text { outer } \\
\text { 内外同質 }\end{array}$ & \multicolumn{3}{|c|}{$\begin{array}{l}06,1-1,3 \mathrm{~m}, 0 \text {, No change } 38,1-1,1.5 \mathrm{~m}, 0 \text {, No change } \\
08,1-1,8 \mathrm{~m}, 0 \text {, Reduce } 44,1-1,6.8 \mathrm{~m}, 0 \text {, Reduce } \\
09,1-1,5 \mathrm{~m}, 0 \text {, No change } 58,1-1,6 \mathrm{~m}, 0 \text {, Reduce } \\
14,1-1,2 \mathrm{~m}, 0 \text {, No change } 59,1-2,12.5 \mathrm{~m}, 2 \text {, Reduce } \\
16,1-1,4 \mathrm{~m}, 0 \text {, No change } 65,1-2,7.5 \mathrm{~m}, 2 \text {, Reduce } \\
24,1-5,8,5 \mathrm{~m}, 3 \text {, Reduce }\end{array}$} & \multicolumn{2}{|c|}{$48,2-1,5.5 \mathrm{~m}, 1$, Reduce } & $68,3-2,8.3 \mathrm{~m}, 2, \mathrm{R} \rightarrow \mathrm{I}$ & & \\
\hline Total計 & \multicolumn{3}{|c|}{$11 / 23.4 \%$} & \multicolumn{2}{|c|}{$1 / 4.8 \%$} & $1 / 12.5 \%$ & & 13 \\
\hline $\begin{array}{l}\text { Change of } \\
\text { the space } \\
\text { 空間変化 } \\
\text { を生かす }\end{array}$ & \multicolumn{3}{|c|}{ 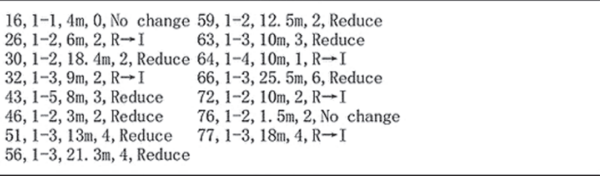 } & \multicolumn{2}{|c|}{$\begin{array}{ll}03,2-1,3.8 \mathrm{~m}, 1 \text {, Increase } & 47,2-2,10 \mathrm{~m}, 3, \mathrm{R} \rightarrow \mathrm{I} \\
05,2-1,7.5 \mathrm{~m}, 1, \mathrm{l} \text {, No change } & 60,2-3,13 \mathrm{~m}, 2 \text {, Reduce } \\
15,2-2,13 \mathrm{~m}, 3 \text {, Reduce } & 50,2-1,14.3 \mathrm{~m}, 1 \text {, No change } \\
18,2-1,1 \mathrm{~m}, 1 \text {, Reduce } & 53,2-1,12 \mathrm{~m}, 1, \mathrm{I} \rightarrow \mathrm{R} \\
20,2-1,6 \mathrm{~m}, 1 \text {, Increase } & 60,2-3,13 \mathrm{~m}, 2 \text {, Reduce } \\
21,2-2,22.5 \mathrm{~m}, 2, \text { Reduce } & 61,2-3,20 \mathrm{~m}, 2, \text { Reduce } \\
28,2-1,11.3 \mathrm{~m}, 1, \mathrm{R} \rightarrow \mathrm{I} & 62,2-1,6 \mathrm{~m}, 1 \text {, Reduce } \\
35,2-1,15 \mathrm{~m}, 1 \text {, Reduce } & \end{array}$} & $\begin{array}{l}07,3-2,9.8 \mathrm{~m}, 2, \mathrm{R} \rightarrow \mathrm{I} \\
22,3-1,16.5 \mathrm{~m}, 1, \text { Reduce } \\
33,3-3,9.8 \mathrm{~m}, 3, \mathrm{R} \text {, Reduce } \\
36,3-4,16 \mathrm{~m}, 4, \mathrm{R} \rightarrow \mathrm{I} \\
37,3-1,8.5 \mathrm{~m}, \mathrm{I}, \mathrm{R} \rightarrow \mathrm{I} \\
41,3-4,8 \mathrm{~m}, 6, \mathrm{R} \rightarrow \mathrm{I} \\
68,3-2,8.3 \mathrm{~m}, 2, \mathrm{R} \rightarrow \mathrm{I}\end{array}$ & $34,4-2,13.4 \mathrm{~m}, 2, \mathrm{I} \rightarrow \mathrm{R}$ & \\
\hline Tota1計 & \multicolumn{3}{|c|}{$15 / 31.9 \%$} & \multicolumn{2}{|c|}{$15 / 71.4 \%$} & $7 / 87.5 \%$ & $1 / 50 \%$ & 38 \\
\hline $\begin{array}{l}\text { 0thers } \\
\text { その他 }\end{array}$ & \multicolumn{3}{|l|}{$10,1-1,2.5 \mathrm{~m}, 0$, No change } & $\begin{array}{l}04,2-1,12 \mathrm{~m}, 2 \text {, Reduce } \\
42,2-1,15 \mathrm{~m}, 1 \text {, No change }\end{array}$ & $75,2-1,6.8 \mathrm{~m}, 1$, Reduce & $27,3-1,6 \mathrm{~m}, 1$, Reduce & & \\
\hline Total計 & \multicolumn{3}{|c|}{$1 / 2.1 \%$} & \multicolumn{2}{|c|}{$3 / 14.3 \%$} & $1 / 12.5 \%$ & & 5 \\
\hline
\end{tabular}


次に、「内外同質」に該当する事例を見ると、ほとんどが「前面配 置」（11/13）に該当する。その内、アプローチ空間の開放性変化の タイプにおいて「無変化」や折れ曲がりのない曲り数「0」が多く見 られ、この $2 つ の$ 条件を共に満たす事例である 06、09、14、16、38 のアプローチ水平距離はすべて $5 \mathrm{~m}$ 以内である。これらのことから、 「内外同質」は、アプローチが長く取れない、折れ曲がれない、ア プローチ空間を変化させにくい場合に多用される傾向が示された。

\section{8. 一般作品との比較}

本章では、前章で検討したアプローチ空間の配置形態と物理構成 に関して、対象作品（竹原作品と記述）を同時期の他の建築家によ り設計された一般的な作品（一般作品と記述）と比較した注 ${ }^{27)}$ 。

\section{1 アプローチ空間の配置形態について}

図 14 は、竹原作品と一般作品のアプローチの設置率注 28)、水平距 離及び曲り数に対する年代ごとの平均值比較図である。（横軸は年代、 縦軸は各項目の数值)

アプローチの設置率において、竹原作品は全般的に高いことが分 かる。アプローチの水平距離においては、1990 年以前の作品だけが 一般作品より短かったが、 1991 年以後は一般作品より長くなる傾向 が窺える。アプローチの曲り数においては、各時期において一般作 品より多いことが示された。

以上のことから、竹原義二の作品はアプローチの配置を重視し、 アプローチ動線を長く取り、折れ曲がりを活用する設計手法を持つ ことが特徴として位置付けられる。

\section{2 アプローチ空間の物理構成について}

図 15 は一般作品のアプローチ空間の空間類型の水平距離の割合 と竹原作品との比較である（上部は竹原作品と一般作品における空 間の類型の模式図、下部は比較の結果を示寸 $100 \%$ 積み上げ横棒グラ フ)。一般作品では、開放的なタイプと見られる(1)が $70 \%$ 以上を占め、 アプローチ空間全体の開放性が強く、空間の開放感と閉鎖感の変化 が少ないことが読み取れた。一方、竹原作品では、(1)の割合が $30 \%$ 未満であり、スキマやトンネル的な空間である(5)と (6)が合計 $40 \%$ を 超えており、空間の開放感と閉鎖感の変化を強調することが分かっ た。

以上のことから、竹原はスキマやトンネル空間を活かすことによ って、変化のあるアプローチ空間を求めていることが分かった。

\section{9. 結論と考察}

本研究は、建築家竹原義二の独立住宅作品のアプローチに着目し、 その特性について、設計意図、配置類型、空間構成及び一般作品と の比較などの解析を通して、アプローチ空間の設計手法を以下のよ うに明らかにした。

（1）多変量分析により、アプローチ空間の長さを意識し、時間軸 を長く取る手法を確認できた。これは本来曖昧な設計意図を定量的 に明確化したが、その時間軸の延長に特化したアプローチの具体的 手法としては：ア、多様な配置形態に加えてアプローチ動線を折れ 曲がりにすることによって動線を長く取る手法。イ、玄関ドアと前 面道路の距離が取れない場合、アプローチ動線を折れ曲がりにする 手法。ウ、限られた敷地でアプローチ動線を長く取れない場合、ア プローチの舗装と玄関の床材を同質にすることで内部と外部を一体

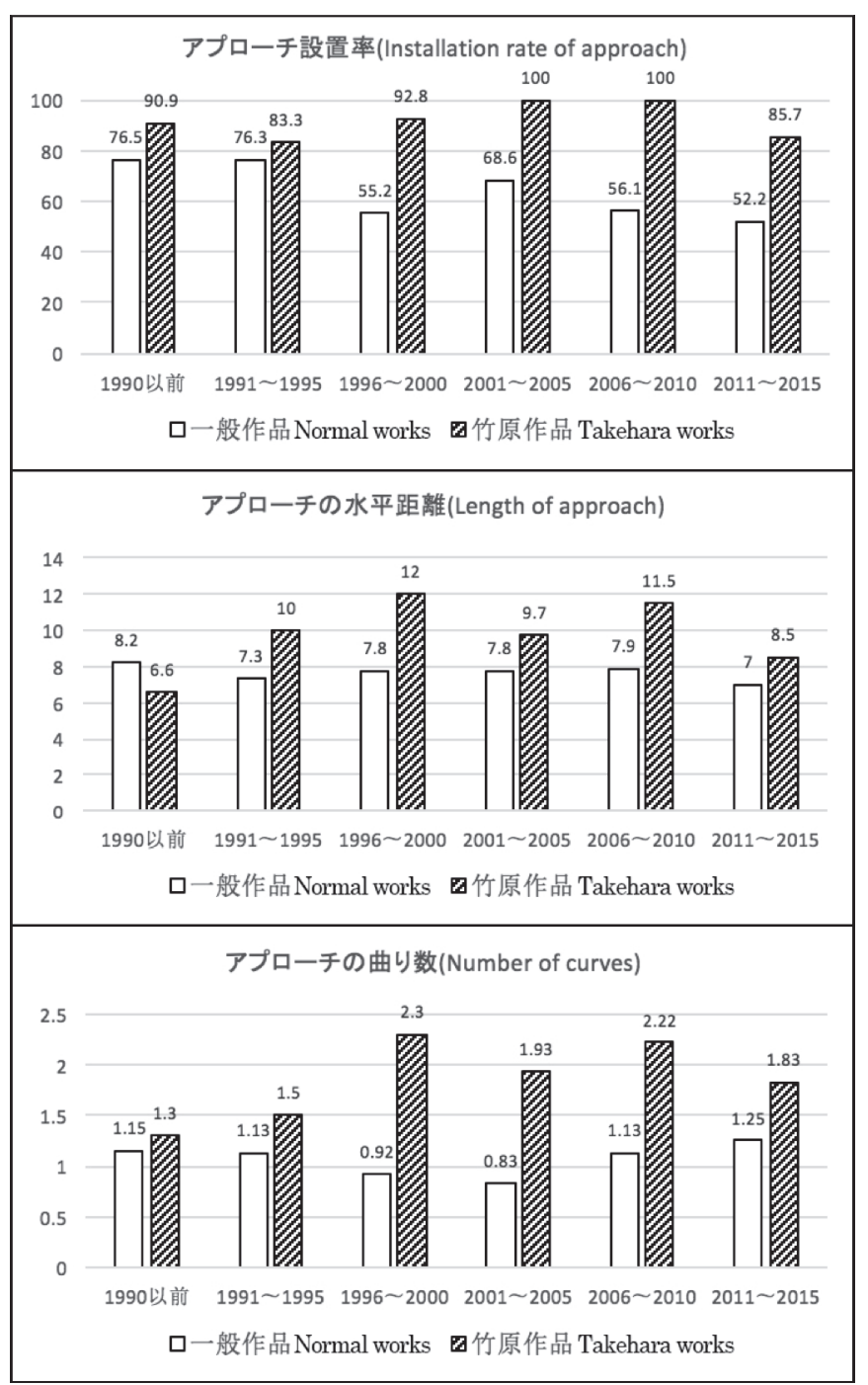

Fig. 14 Comparison of arrangement form

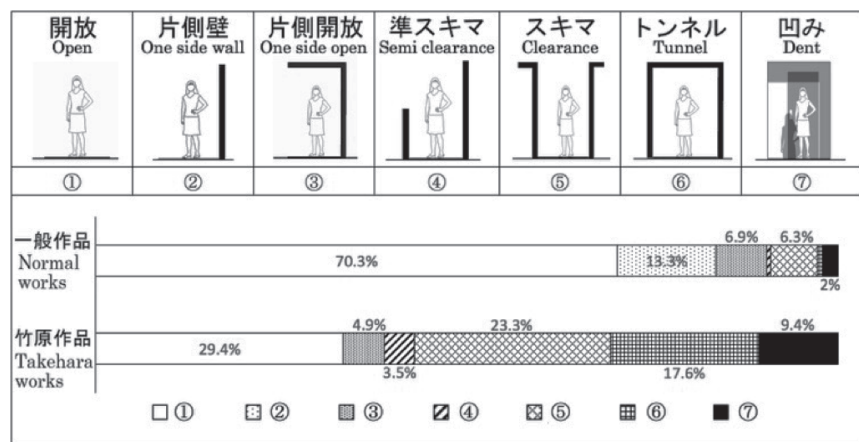

Fig. 15 Comparison of space type constitution

化させ、アプローチを視覚的に長く見せる手法注 ${ }^{29)}$ 。以上の操作は、 住宅に入るまでの移動距離を延長することと、人を立ち止まらせて 向きを変えさせることで、人を容易に玄関に到達させないようにし、 時間的な移行をもたらすことができる。すなわち「距離の延長」、「行 為の延長」によって「時間の延長」をもたらす手法が明らかになっ た。これらの手法は、限られた空間を広く感じさせる効果につなが っている。

（2）アプローチに豊富な空間の体験をもたらした。具体的手法と しては、延長したアプローチ動線において建築外壁や自立壁に挟ま れたスキマ、トンネル空間を抜け通らせることで、開放的な空間と 
より閉鎖的な空間との対比をもたらし、空間の限定性を変化させる アプローチ空間を作り出している。これにより、空間の開放感と閉 塞感、明と暗の変化に富んだアプローチ景観が形成され、風や光な ど自然の動きも感じ取りながら官能的な移行をもたらすことで、よ り多様な空間体験ができるようになっている。

近年独立住宅の敷地が狭小化し続ける背景の下、設計者として施 主を説得し、限定された用地により広いスペースを占めるアプロー チを設けることは簡単とは言えない。このことから竹原が考えたア プローチは魅力的であると言える。アプローチの配置を重視する竹 原義二は、上記の手法を用い、アプローチの形態と空間を複雑化さ せることで、限られた空間を広く感じさせることを目指している。 そして、家に入るまでに時間的な移行と官能的な移行をつくりだす ことで、面積以上の広がり感をもたらすことができた。その結果、 人々はこの空間から豊富な体験を得られるようになった。作品が実 現していることは、多くの汎用性のある共感を得ているといえ、竹 原が複雑なアプローチを実現できる理由だと考えられる。

本稿で明らかとなった竹原義二によるアプローチの設計手法は難 しいものではなく、新たな住宅設計やリゾート施設など人の暮らし を基底に据えた建築の設計に特に参考になると考えられる。このよ うにアプローチ空間をちょっと工夫することで住宅全体のイメージ アップや空間体験が豊富になる手法を生かすことができ、日本の住 宅設計を一層豊かにすることが可能になる。また、本稿はアプロー チ空間の設計を住宅内外空間の関係に関する解析の切り口として進 められたが、竹原義二の住宅作品に見る外部空間と内部空間とのつ ながり手法の研究は今後の課題としたい。

\section{謝辞}

本研究の解析方法や論文作成についてご助言を頂いた兵庫県立大 学大学院緑環境景観マネジメント研究科の沈悦教授、及び貴重な話 しを聴かせて頂いた竹原義二様に御礼を申し上げます。

\section{参考文献}

1) Takehara, Y. : Takehara Yoshiji Residential Architecture, TOTO LTD, 2010.4(in Japanese)

竹原義二：竹原義二の住宅建築, TOT0 出版, 2010.4

2) Takehara, Y. : Muu, Gakugei Publish, 2007. 3(in Japanese) 竹原義二: 無有, 学芸出版社, 2007.3

3) Takehara, Y. : Dense of Approach, Detail 2006-01, P60-63 (in Japanese) 竹原義二：アプローチの濃密さを決める, ディテール, 2006-01, P60-63

4) Takehara, Y. : Reading the Force of Field, Jutakutokushu 1995-09, P86-97 (in Japanese)

竹原義二：場の力を読む，住宅特集 1995-09, P86-97

5) Kobayashi, F. and Fujie, M. : Approach of Resident, Detail, 2009-10, P45 (in Japanese)

小林和教, 藤江通昌：住宅のアプローチ空間, ディテール，2009-10, P45

6) Hirano, T. : Between Street and Home, Jutakukenchiku, 2002-08, P102103 (in Japanese)

平野敏之：街と家の間, 住宅建築, 2002-08, P102-103

7) Miyawaki, M. : House Design Method of Miyawaki Mayumi, Maruzen, 1987. 6 (in Japanese)

宮脇檀：宮脇檀の住宅設計ノウハウ，丸善株式会社，1987.6

8) Tsukamoto, Y. and Sakamoto, K. : Spatial Articulation and Connection in Japanese Contemporary Houses - A Study On Architectural Composition of the House, Journal of Architecture, Planning and Environmental Engineering (Transactions of AIJ), No. 465, pp. 85-93, 1994. 11 (in Japanese)

塚本由晴, 坂本一成：現代日本の住宅作品における空間の分節と接続一住 宅建築の構成形式に関寸る研究, 日本建築学会計画系論文集, 465, pp. 85-93, 1994. 11

9) Tsukamoto, Y. and Sakamoto, K. : Spatial Division in Japanese
Contemporary Houses - A Study on Architectural Composition of the House, Journal of Architecture, Planning and Environmental Engineering (Transactions of AIJ), No.478, pp.99-106, 1995.12(in Japanese)

塚本由晴, 坂本一成：現代日本の住宅作品における空間の分割一住宅建築 の構成形式に関する研究，日本建築学会計画系論文集，478, pp. 99-106, 1995. 12

10) Nemoto, R. and Sakamoto, K. : Spatial Composition by Form of Room and Arrangement of Interior Elements in Contemporary Houses: A Study on Spatial Composition in Contemporary Houses, Journal of Architecture and Planning (Transactions of AIJ), No.654, pp. 1889$1895,2010.8$ (in Japanese)

根本理恵, 坂本一成：住宅の主室における室形状と室内要素の配列による 空間構成一現代住宅作品の構成に関する研究, 日本建築学会計画系論文集, 654, pp. 1889-1895, 2010.8

11) Kogawa, J., Onoda, T. and Sakamoto, K. : Composition of Outside Volumes and Rooms in Contemporary Japanese Houses- Architectural Composition of Contemporary Japanese Houses in Terms of Relation Between Interior and Exterior, Journal of Architecture, Planning and Environmental Engineering (Transactions of AIJ), No.537, pp. 117123, 2000.11 (in Japanese)

小川次郎, 小野田環, 坂本一成：外形ヴォリュームと室の配列による建築の 構成一現代日本の住宅作品における内外の関係による構成形式, 日本建築 学会計画系論文集, 537, pp. 117-123, 2000.11

12) Endo, K., Shiozaki, T. and Okuyama, S. : Relationship Between the Boundary of Site and the Outline of Plan in Contemporary Japanese Houses Located on the Irregular Shaped Site- A study on the correspondence of architecture to the site, Journal of Architecture and Planning (Transactions of AIJ), No.709, pp. 579-589, 2015.3(in Japanese)

遠藤康一, 塩崎太伸, 奥山信一 : 敷地境界との関係にみる不整形敷地に建つ 住宅作品の平面輪郭一建築と敷地の対応関係に関する研究, 日本建築学会 計画系論文集，709，pp. 579-589, 2015.3

13) Murata, R., Negayama, A. and Yasuda, K. : Furnishing of Courtyards and Connection with Living Rooms in Contemporary Japanese Courtyard Houses, Journal of Architecture and Planning (Transactions of AIJ), No. 676, pp. 1365-1371, 2012.6 (in Japanese)

村田涼, 根ヶ山愛子, 安田幸一: 現代日本のコートハウスにおける中庭の設 えと居間との連繋, 日本建築学会計画系論文集, 676, pp. 1365-1371, 2012.6

14) Okamura, K., Kogawa, J. and Sakamoto, K. : Composition of Urban Contemporary Japanese Houses by Arrangement and Connection of Exterior Spaces: Architectural Composition of Contemporary Japanese Houses in Terms of Relation Between Interior and Exterior (2), Journal of Architecture, Planning and Environmental Engineering (Transactions of AIJ), No. 552, pp. 141-146, 2002.2(in Japanese) 岡村航太, 小川次郎, 坂本一成 : 外部空間の配列と接続からみた都市型住宅 作品の構成一現代日本の住宅作品における内外の関係による構成形式 (2), 日本建築学会計画系論文集，552, pp. 141-146, 2002.2

15) Tsukamoto, Y., Hanjo, A. and Sakamoto, K. : Articulated Exterior in Japanese Contemporary Houses: A Study on Architectural Composition if the House, Journal of Architecture, Planning and Environmental Engineering (Transactions of AIJ), No. 470, pp. 95-104, 1995. 4 (in Japanese)

塚本由晴, 繁昌朗, 坂本一成：現代日本の住宅作品における外部空間の分節 と統合一住宅建築の構成形式に関する研究, 日本建築学会計画系論文集, 470, pp. 95-104, 1995. 4

16) Murata, R., Nagano, T. and Yasuda, K. : The Arrangement and Openness of Outdoor Spaces in Contemporary Japanese Courtyard Houses, Journal of Architecture and Planning (Transactions of AIJ), No. 661, pp. 569576, 2011. 3(in Japanese)

村田涼, 永野敏幸, 安田幸一：現代日本コートハウスにおける外部生活空間 の配置と開放性，日本建築学会計画系論文集，661，pp. 569-576, 2011.3

17) Ohi, T. : Study of Entrances to The Modern Houses by Isoya YoshidaModern Trends Toward Layout and Functional Similarity of Uchi-Genkan and Katte-Guchi, Journal of Architecture and Planning (Transactions of AIJ), No. 704, pp. 2299-2306, 2014.10(in Japanese) 大井隆弘：吉田五十八の住宅作品を通してみる近代住宅の出入口一勝手口 の減少および内玄関と勝手口の近接傾向について, 日本建築学会計画系論 文集，704，pp. 2299-2306，2014. 10 
18) Fuchu, T., Korenaga, M., Shibata, A. and Kaneko, S. : Flexibility of Main Spaces Thorough Partitions in Houses Designed by Seike Kiyosi, Journal of Architecture and Planning (Transactions of AIJ), No. 624 , pp. 465-470, 2008. 2 (in Japanese)

府中拓也, 是永美樹, 柴田晃宏, 金子晋也： 清家清の住宅作品における建具 を介した主空間の伸縮性，日本建築学会計画系論文集，624，pp. 465-470， 2008. 2

19) Kobayashi, T., Suzuki, T., Masubara, S. and Kita, M. : Design of Darkness in Architectural Space Case Study of Takehara Yoshiji's Houses, Report of Kinki Branch (Transactions of AIJ), pp. 101-104, 2013. 5 (in Japanese)

小林智行, 鈴木毅, 松原茂樹, 木多道宏：建築空間における暗さのデザイン の研究一建築家竹原義二を事例として, 日本建築学会近畿支部研究発表会, pp. 101-104, 2013. 5

20) Tetauchi, M., Murata, J. and Sakamoto, K. : Composition of Approach Space in Contemporary Japanese Architecture: A Study on Composition of Exterior Space (2), Journal of Architecture, Planning and Environmental Engineering (Transactions of AIJ), No. 525, pp. 129135, 1999.11 (in Japanese)

寺内美紀子, 村田淳, 坂本一成：現代日本の建築作品における外形構成とア プローチ空間ー一領域的開放性からみた外部空間の構成形式に関する研究 (2)，日本建築学会計画系論文集，525，pp. 129-135，1999.11

21) Suzuki, N., Shimizu, H., Yamaguchi, M. and Sugimoto, M. : A Study on the Walk Experience in Approaching Spaces, Journal of Architecture, Planning and Environmental Engineering (Transactions of AIJ), No. 486, pp. 51-59, 1996.8(in Japanese)

鈴木信弘, 志水英樹, 山口満, 杉本正美：アプローチ空間における歩行体験 に関する研究，日本建築学会計画系論文集，486, pp. 51-59, 1996.8

22) Shinohara, 0. : Civil Landscape Planning, Gihodo Publish, 1982.6(in Japanese)

篠原修：新体系土木工学 59 土木景観計画，技報堂出版，1982.6

注

注 1）参考文献 1）のP296 により、竹原は 2010 年（文献の出版年）まで 150 件の作品ができ、1978 年に竣工した 1 番目の作品「勢野の家」から 1 年に 約 4.8 件のペースである。

注 2）参考文献 1）のP138 で、藤森照信が「竹原義二の作品も名前も日本の 建築界ではよく知られている。大阪を代表する住宅作家として広く名は通 つている。」と評価した。

注 3）独立住宅作品だけを見ると、2015 年に竣工した「十ノ坪の家」まで、 竹原義二の作品は専門雑誌に計 96 回掲載された。これ以外は非独立住宅作 品もいくつか掲載され、計 100 回以上がある。

注 4）参考文献 1）の P296 で、花田佳明が「これら 150 作品を通覧して驚くの は、完成度の一貫した高さと、それらをいくつかのスタイル、あるいは時 期へと分類し区分することの難しさだ。変化のあるとすれば、増加した年 間竣工件数だけだとすら言いたくなる。（中略）それほどに 150 作品のレ ボェルは揃っており、あたかも最初からすべて竹原の頭の中にあったかの ようだ。しかしこの多様性は、実際には 30 歳から 60 歳までの時間の中で 生み出されており、彼の早熟ぶりと才能の安定性を示寸証拠以外の何もの でもない」と評価した。

注 5）「初めて訪れる住宅は、とても心がワクワクする。そこに住む人の気持 ちが伝わってくるようなアプローチ空間について、住宅の設計を始まった 時から随分と考えている。」（参考文献 3、P60)

注 6)「僕はいつも立ち止まるという行為が重要だと考えています。立ち止ま るというのは、距離が短ければ短いほどとても大事になってくるように思 います。」（参考文献 4、P88)

注 7）「玄関へは容易に到着させない。敷地に余裕がなく、アプローチ空間を ほとんど取ることができないでも、必ず一度は立ち止まらせる。」（参考 文献 2、P103)

注 8）参考文献 5)、P45

注 9）「初めて建主の敷地を見せていただいたとき、脳裏をかすめることの 一つとして、玄関をどこに位置させるのかがある。それはとりもなおさず 建主一気持ちのよいアプローチ空間を提案したいからにほかならない。」 (参考文献 6、P102)

注 10）「敷地が狭くなる一方なので、そういう長いアプローチをつくろうと すると、敷地の脇に寄せられてどうしても狭い路地ふうになる。しかしそ の路地にグラウンドカバリングや踏み石を慎重にセットし、傘をさして十 分通れるだけの幅をクリアし、照明器具や焦点に見える玄関回りのデザイ ンのちゃんとしたアプローチをつくると、その家がかなり立派な家風にな る。(中略) 私の設計でも、出来るならそんな奥行きのある感じの風情を 生みだしたくて、何度も試みる。」(参考文献 7、P266)
注 11）参考文献 8），9，10）とその他があげられる。

注 12）参考文献 11)，12），13）とその他があげられる。

注 13）参考文献 14），15，16）とその他があげられる。

注 14）参考文献 17)。

注 15）参考文献 18）

注 16）参考文献 19)。

注 17）参考文献 20)。

注 18）参考文献 21)

注 19）対象作品は、竹原義二の独立住宅作品のうち、国内の代表的な専門雑 誌「住宅特集」、「住宅建築」と「建築文化」に掲載された、分析に十分な 資料を得られる 78 点の作品とした。

注 20）本研究のアプローチは、道路から玄関ドアまでの動線と定義する。玄 関が明確されていないや複数の入り口がある場合、筆者が図面から主要ア プローチ動線を判断し、作品ごとに 1 つのアプローチを解析する。

注 21）対象事例全体のアプローチにおいて、ほぼすべての曲りの節点は $90^{\circ}$ のカーブであり、ほかに $90^{\circ}$ 未満や $180^{\circ}$ のカーブも散見する。そこで本 研究は、 $90^{\circ}$ 及び $90^{\circ}$ 未満のカーブを 1 回の折れ曲がりとしてカウントし、 $180^{\circ}$ のカーブを 2 回としてカウントする。

注 22）本研究は、アプローチの起点の所在道路を前面道路と定義し、この基 準により建物の立面を前面、側面、背後に分けている。

注 23）本研究で検討したアプローチ空間の限定性は、アプローチ動線の両开 イドや上空に物理的な遮蔽があるかどうかによる空間の開放程度を指す。 注 24）事例 No. 4 におけるアプローチの折れ曲がりは A〜H に該当しないた め、Xと記述する。

注 25）本研究は建物の位置に関わらず、玄関ドアを前面道路とより遠いとこ ろに配置することや、アプローチ動線を必要以上折れ曲がらせることによ つて、アプローチ動線を延長された事例を「動線を長く取る」に該当する。

注 26）本研究は玄関ドアの位置と向きに関わらず、アプローチを沿いて前面 道路から玄関ドアに入るまで必要以上折れ曲がった事例を「折れ曲がりに する」に該当する。

注 27）一般作品は、「住宅特集」1985 年〜2015 年に掲載された、竹原作品の 立地条件と近い関西地区における、分析に十分な資料が得られる計 353 件 の独立専用住宅作品を抽出して集計した。敷地面積において、竹原作品の

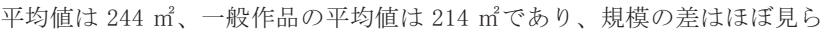
れない。

注 28）本章では、全作品に対してアプローチの水平距離が 3 米以内の作品を アプローチなしと見られる。アプローチの設置率とは、水平距離が 3 米以 上の作品の割合である。

注 29) 篠原修が「類同の法則」を申し立て、「他の条件が一定ならば、類似の 対象はまとまって見える」と記述した。従って、内部と外部の舗装を同質 にすることはアプローチと玄関を視覚的に一つに見えることができると考 えられる。（参考文献 22, p103）

Appendix : List of objects

\begin{tabular}{|c|c|c|c|c|c|c|c|}
\hline No. & Name of works & $\mathrm{Y} / \mathrm{M}$ & Published & No. & Name of works & $\mathrm{Y} / \mathrm{M}$ & Published \\
\hline 1 & 西明石の家 & 8303 & 住宅特集1985夏 & 40 & 六番町の家 & 0004 & 住宅建築2006-06 \\
\hline 2 & 粉浜の家 2 & 8502 & 住宅特集1986-06 & 41 & 䉆林寺南町の家 & 0006 & 住宅特集2000-09 \\
\hline 3 & 媣井中町の家 & 8512 & 住宅特集1987-01 & 42 & 東豊中の家 & 0102 & 住宅特集 2001-09 \\
\hline 4 & 阿弥の家 & 8612 & 住宅特集 1987-08 & 43 & 箱作の家 & 0104 & 住宅特集2001-09 \\
\hline 5 & 依羅通りの家 & 8709 & 住宅建築1993-05 & 44 & 加守町の家 & 0108 & 住宅建築2005-03 \\
\hline 6 & 石丸の家 & 8805 & 住宅特集 1989-07 & 45 & 明石の家 & 0108 & 住宅特集 2002-05 \\
\hline 7 & 西中島の家 & 8809 & 住宅建築1993-05 & 46 & 高柳の家 & 0109 & 住宅建築2005-03 \\
\hline 8 & 楠町の家 & 8812 & 住宅特集1989-04 & 47 & 大社町の家 & 0112 & 住宅建築2005-03 \\
\hline 9 & 千里山の家 & 8903 & 住宅特集 1990-02 & 48 & 101番目の家 & 0205 & 住宅特集 2002-12 \\
\hline 10 & 寿町の家 & 8904 & 住宅特集1990-02 & 49 & 岩倉の家 & 0207 & 住宅建築2005-03 \\
\hline 11 & 本庄町の家 & 8907 & 住宅特集 1990-02 & 50 & 都島の家 & 0212 & 住宅建築2006-06 \\
\hline 12 & 吉見，里の家 & 9011 & 住宅特集1991-11 & 51 & 河内山本の家 & 0301 & 住宅建築2006-06 \\
\hline 13 & 御崎の家1 & 9111 & 住宅建築1993-06 & 52 & 芦屋の家 & 0312 & 住宅建築2006-06 \\
\hline 14 & 御園の家 & 9112 & 住宅特集1992-09 & 53 & 額田の家 & 0404 & 住宅特集2004-08 \\
\hline 15 & 真法院町の家 & 9205 & 住宅特集 1992-11 & 54 & 御宿の家 & 0411 & 住宅特集2005-02 \\
\hline 16 & 山坂の家1 & 9206 & 住宅特集1992-11 & 55 & 粉浜の家 4 & 0503 & 住宅特集 2006-01 \\
\hline 17 & 玉串川の家 & 10 & 住宅特集1993-02 & 56 & 岸和田の家05 & 0505 & 住宅特集2006-05 \\
\hline 18 & 印田の家 & 9303 & 住宅特集 1993-11 & 57 & 北恩加島の家 & 0506 & 住宅建築2006-06 \\
\hline 19 & 千里園の家 & 9305 & 住宅特集1993-09 & 58 & 宮/谷の家 & 0512 & 住宅特集2007-05 \\
\hline 20 & 小路の家 & 9308 & 住宅特集 1994-11 & 59 & 北畠の家 & 0609 & 住宅特集2007-09 \\
\hline 21 & 久御山の家 & 9312 & 住宅特集 1994-05 & 60 & 媣谷の家 & 0701 & 住宅特集 2007-09 \\
\hline 22 & 御崎の家2 & 9404 & 住宅特集19 & 61 & 諏訪森町中の家 & 0704 & 住宅建築2008-08 \\
\hline 23 & 朱雀の家 & 9411 & 住宅特集1995-05 & 62 & 諏訪森町東の家 & 0706 & 住宅建築2013-02 \\
\hline 24 & 宝山町の家 & 9505 & 住宅特集1996-02 & 63 & 乗鞍の家 & 0711 & 住宅特集2008-09 \\
\hline 25 & 帝塚山の家 & 9505 & 住宅特集 1996-02 & 64 & 小倉町の家 & 0803 & 住宅特集 2009-04 \\
\hline 26 & 向陵中町の家 & 9601 & 住宅特集 1996-05 & 65 & 永山園の家 & 0805 & 住宅建築2008-08 \\
\hline 27 & 魚崎北町の家 & 96 & 住宅特集 1997-02 & 66 & 富土か “丘の家 & 0903 & 住宅特集2010-08 \\
\hline 28 & 山坂の家2 & 9611 & 住宅特集1997-02 & 67 & 大川の家 & 0908 & 住宅特集2011-10 \\
\hline 29 & 浜松の家 & 9701 & 建築文化 $2000-03$ & 68 & 山本町北の家 & 0911 & 住宅特集2013-02 \\
\hline 30 & 南河内の家 & & 住宅特集 1997-08 & 69 & 西春の家 & 1002 & 住宅建築2013-02 \\
\hline 31 & 目神山の家 & 9702 & 建築文化2000-03 & 70 & 東淀川の家 & 1102 & 住宅建築2013-02 \\
\hline 32 & 東広島の家 & 9703 & 住宅特集1997-10 & 71 & 緑町の家 & 1103 & 住宅特集2013-02 \\
\hline 33 & 広陵町の家 & 9706 & 住宅特集 1997-08 & 72 & 新千里南町の家2 & 1110 & 住宅建築 2015-02 \\
\hline 34 & 城崎の家 & 97 & 建築文化2000-03 & 73 & 東松山の家 & 1301 & 住宅特集 2013-07 \\
\hline 35 & 千里丘の家 & 9804 & 住宅特集1999-04 & 74 & 豊中の家 & 1305 & 住宅建築2015-02 \\
\hline 36 & 新千里南町の家 & 9812 & 建築文化 $2000-03$ & 75 & 五力田の家 & 1305 & 住宅建築2015-02 \\
\hline 37 & 夙川の家 & 9901 & 住宅特集1999-10 & 76 & 住吉本町の家 & 1305 & 住宅建築2015-02 \\
\hline 38 & 武蔵小金井の家 & 9901 & 住宅特集1999-04 & 77 & 金岡の家 & 1312 & 住宅建築2015-02 \\
\hline 39 & 比㕡平の家 & 0001 & 住宅特集2000-05 & 78 & 十ノ坪の家 & 1502 & 住宅特集2015-04 \\
\hline
\end{tabular}




\title{
A STUDY ON THE APPROACH ARRANGEMENT METHOD \\ IN DETACHED HOUSE WORKS OF YOSHIJI TAKEHARA
}

\author{
Luyang $L I^{* 1}$ and Shuhei ENDO*2 \\ ${ }^{* 1}$ Graduate School of Engineering, Kobe Univ., M.Eng. \\ *2 Prof., Graduate School of Engineering, Kobe Univ., Dr.Eng.
}

Japanese architect Yoshiji Takehara, has completed lots of architecture projects, especially in the field of housing, mainly in Kansai area. There are also lots of great dwelling practices like Kindergarten and elderly housing. Thus, he is considered as the master architect in housing design. Since 1980th, he has got significant attention because that his works are published on variety of Japanese architecture magazines more than 100 times.

This productive architect, keeps capturing attention for decades. After analyzing his works, the author capture its features. The most important one is the arrangement of approach. For example, in his works, by bending the approach flow, it makes approach tortuous and ambiguous. This kind of study is important when analysis design method of detached house. So far, the studies about the relationship between inner and outer space of Japanese detached house are almost all focus on the position relationships or connecting method between both space. Nearly no study about the house approach's method have been found. Therefore, this study focuses on analyzing the approach space design method in Yoshiji Takehara's detached house works.

The cases of this study are 78 detached house works designed by Yoshiji Takehara, which are published on main architecture magazines with adequate study material.

Based on the study for Yoshiji Takehara's words and the result of interview with him, this paper summarizes the keywords for Yoshiji Rakehara's approach design method and concludes the items to be analyzed. Those items are: the design intention of approach which is obtained from his comment of his works, the classification for approach layout, the regression analysis for the approach data, the space composition of approach and its variation, the comprehensive analysis of the items above, and the comparison with normal works in the same decades about the approach design method. The results are as follows:

1). The time axis of approach has been extended by extending the overall length of streamline and adding turn, thus creates a transitional space before entering the house and makes the limited space widely felt.

2). A variety of spatial experience of approach have been made by arranging space with different limitation. Thus increased the contrast of approach space and brings sensual transitions and diverse spatial experiences.

Yoshiji Takehara ingeniously integrates the traditional Japanese tea house layout into the contemporary housing design by applying the method of approach. He gives an answer to the relationship between human and nature in contemporary housing design. Especially for the reality that residential land becomes smaller and smaller, the approach method for where it is impossible to be complicated proves to be an effective way to make a tiny space not visibly tiny and the experience before entering the house is enriched. Lots of work using this method has already been built, meaning this method strikes a popular chord. 